\title{
Review
}

\author{
Giuseppe Lapergola, Alessandro Graziosi, Ebe D’Adamo, Patrizia Brindisino, \\ Mariangela Ferrari, Anna Romanelli, Mariachiara Strozzi, Roberta Libener, \\ Danilo A. W. Gavilanes, Antonio Maconi, Angela Satriano, Alessandro Varrica and \\ Diego Gazzolo*
}

\section{S100B in cardiac surgery brain monitoring: friend or foe?}

https://doi.org/10.1515/cclm-2021-1012

Received September 13, 2021; accepted December 29, 2021; published online January 11, 2022

\begin{abstract}
Recent advances in perioperative management of adult and pediatric patients requiring open heart surgery (OHS) and cardiopulmonary bypass (CPB) for cardiac and/or congenital heart diseases repair allowed a significant reduction in the mortality rate. Conversely morbidity rate pattern has a flat trend. Perioperative period is crucial since OHS and CPB are widely accepted as a deliberate hypoxic-ischemic reperfusion damage representing the cost to pay at a time when standard of care monitoring procedures can be silent or unavailable. In this respect, the measurement of neuro-biomarkers (NB), able to detect at early stage perioperative brain damage could be especially useful. In the last decade, among a series of NB, S100B protein has been investigated. After the first promising results, supporting the usefulness of the protein as predictor of short/long term adverse neurological outcome, the protein has been progressively abandoned due to a series of limitations. In the present review we offer an up-dated overview of the main S100B pros and cons in the perioperative monitoring of adult and pediatric patients.
\end{abstract}

*Corresponding author: Prof. Diego Gazzolo, Neonatal Intensive Care Unit, G. d'Annunzio University, 65100 Chieti, Italy, Phone: +39 0871 358219, E-mail: dgazzolo@hotmail.com Giuseppe Lapergola, Alessandro Graziosi, Ebe D’Adamo, Patrizia Brindisino, Mariangela Ferrari and Anna Romanelli, Neonatal Intensive Care Unit, G. d'Annunzio University, Chieti, Italy Mariachiara Strozzi, Roberta Libener and Antonio Maconi, Department of Maternal, Fetal and Neonatal Medicine, ASO SS Antonio, Biagio and C. Arrigo, Alessandria, Italy

Danilo A. W. Gavilanes, Department of Pediatrics and Neonatology, Maastricht University, Maastricht, The Netherlands Angela Satriano and Alessandro Varrica, Department of Pediatric Cardiac Surgery, IRCCS San Donato Milanese Hospital, Milan, Italy
Keywords: brain injury; cardiac surgery; cardiopulmonary bypass; neurobiomarker; neuromonitoring; S100B.

\section{Introduction}

Congenital heart diseases (CHD) are a heterogeneous entity characterized by anatomic malformations of the heart and/or great arteries occurring during intrauterine development [1, 2]. CHD comprise $28 \%$ of all major congenital anomalies and the incidence is estimated at 8-9 per 1,000 live births per year [3]. Given a worldwide annual birth rate of around 150 million, this means that each year 1.3 million infants are born with CHD [1-4]. Approximately 30\% of neonates born with CHD are critical and need surgical correction within the first year of life to avoid early death. Neurocognitive developmental damage is present in $50 \%$ of the survivors [1-5].

In the last few decades, open heart surgery (OHS) by means of cardiopulmonary by-pass (CPB) has raised survival incidence from 67\% (1979-1993) to 89\% (1994-2005) [6]. Conversely, perioperative and long-term morbidity have increased, especially for complex CHD [6]. At this stage, the keyword for health care systems is "reducing morbidity". Among main standard interventions, prenatal ultrasound screening (PUS) for early CHD diagnosis is the preferred option in developed countries: in non-cyanotic CHD, PUS can improve the success of fetal cardiac interventions and can guarantee appropriate preparation for delivery and the post-neonatal period. However, the rate of abortion as a last resort for complex CHD management is still increasing $[7,8]$.

The quality of perioperative monitoring both in children and adults is crucial in order to promptly detect cases at risk of OHS complications, thus preventing or minimizing neurological damage. Today, despite accurate perioperative longitudinal neuro-monitoring by means of electroencephalography (EEG) or amplitude-integrated electroencephalography (aEEG), transcranial Doppler (TCD) and near-infrared 
spectroscopy (NIRS), brain damage can occur at a stage when standard procedures may be silent or unavailable [9-15]. Thus, the inclusion in daily clinical practice of new tools such as neuro-biomarkers (NB), able to provide useful information about well-being/stress on the central nervous system (CNS) during OHS, are eagerly awaited. In this light and especially in infants and children, the Food and Drug Administration (FDA), the European Medicines Agency (EMA) and the National Institutes of Health (NIH) have recently established a series of criteria which must be met for NB inclusion in clinical practice [16-18]. In adults, newer and more useful neuromonitoring strategies in OHS are still of great interest for the improvement of quality of life [19]. Literature data reported that the monitoring of S100B protein in non-CHD infants and traumatic brain injured children has already been included in daily clinical practice [20,21]. However, no consensus has been found on the usefulness of the protein in CNS perioperative monitoring of CHD population and of adult patients.

Therefore, the purpose of the present review is to investigate the pros and cons of $\mathrm{S100B}$ protein assessment in the perioperative period of CHD infants and adult $\mathrm{OHS}$ population.

\section{Research strategy}

The literature review was performed by conducting electronic searches of MEDLINE (via PubMed and PubMed Central), EMBASE, CINHAL and the Cochrane Library. The electronic search used the following keywords and $\mathrm{MeSH}$ terms: (i) congenital heart diseases AND (S100 OR S100beta OR S100 protein OR S100B OR biomarkers of cerebral damage); (ii) cardiac surgery AND (S100 OR S100beta OR S100 protein OR S100B OR biomarkers of cerebral damage); (iii) cardiopulmonary bypass AND (S100 OR S100beta OR S100 protein OR S100B OR biomarkers of cerebral damage); (iv) brain monitoring in cardiac surgery AND (S100 OR S100beta OR S100 protein OR S100B OR biomarkers of cerebral damage); (v) neurological damage in cardiac surgery AND (S100 OR S100beta OR S100 protein OR S100B OR biomarkers of cerebral damage). No publication date limits were set. To enable full understanding of the studies, the inclusion criteria were: (i) primary (original) research published in a peer-reviewed journal in the English language and (ii) full text available. For the same reason, case reports, commentaries, letters to the editor, and reviews were excluded. Articles including data related to animal models were also excluded. Literature searches were performed in the period between 1 January 2019 and 1 November 2020 .

\section{Cardiopulmonary by-pass}

The performance of CPB in adults and CHD infants varies according to the complexity of the disease. In adult patients, $\mathrm{CPB}$ is performed in the majority of cardiac surgery procedures including coronary artery bypass grafting, valvular repair/replacement, complex CHD repair [22]. In infants, data reported that the incidence of $\mathrm{CPB}$ has increased dramatically, especially for cyanotic CHD repair [6]. The primary objective of OHS-CPB is to guarantee cardiac output and multi-organ oxygenation maintaining a more stable cerebral blood flow throughout surgery. Although such perioperative management decreased neurological morbidity, brain damage still remains a major post-operative complication both in adults and in children [23-32]. Intraoperative interventions (CPB and circulatory arrest techniques), inadvertent events from surgical procedures (thromboembolic events, strokes, intracranial hemorrhage), and uncorrectable hypoxia/cyanosis in the post-operative period are considered the main responsible factors in neurodevelopmental outcomes in these patients [19, 23-27, 32]. Moreover, brain injury enhancing factors such as hyperthermia, hyperglycemia and systemic inflammatory response during the perioperative period also contribute to the development of such complications [33].

The mechanisms underlying the development of brain injury during and after cardiac surgery is mainly due to hypoxic-ischemic (HI) insult, followed by the reperfusion phase and more recently the so-called "third phase", which continues for weeks and months after the primary insult [34]. Soon after HI insult, primary energy failure occurs with deprivation of the glucose and oxygen supply resulting in a switch to anaerobic metabolism and deleterious effects on vascular autoregulation. The advancing of HI injury actives a biochemical cascade leading to cellular injury [34-40]. Secondary energy failure occurrence varies according to insult characteristics with onset at about 8-16 h and a nadir at about $24-48 \mathrm{~h}$. Finally, gliosis, persistent inflammatory receptor activation and epigenetic changes are responsible for the tertiary phase (Figure 1) [35-43].

\section{CPB and neurological pattern in adults}

In adults, short (memory and visuospatial ability loss) and long-term (ischemic stroke, cognitive decline) neurocognitive impairment are commonly encountered after OHS and CPB [43-46]. Minute fatty micro-emboli constitute the major source of post-OHS neurological dysfunction 


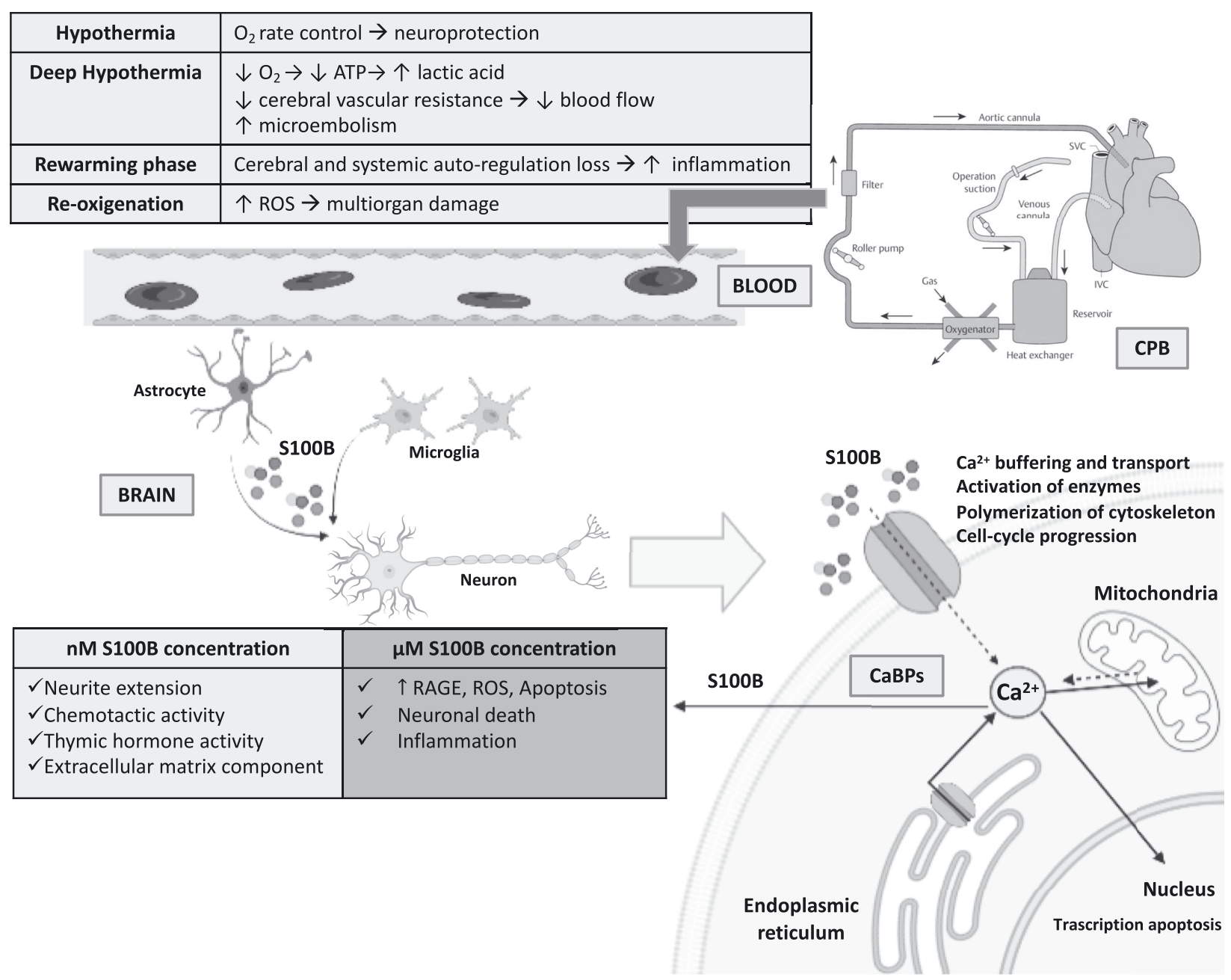

Figure 1: Biochemical cascade of events involving $\mathrm{S} 100 \mathrm{~B}$ protein in patients undergone to open heart surgery and cardiopulmonary bypass. $\mathrm{O}_{2}$, oxygen; ATP, adenosine triphosphate; ROS, reactive oxygen species; SVC, superior vena cava; IVC, inferior vena cava; CPB, cardiopulmonary bypass; $\mathrm{Ca}^{2+}$, calcium; $\mathrm{nM}$, nanomolar; $\mu \mathrm{M}$, micromolar; $\mathrm{CaBPs}, \mathrm{Ca}^{2+}$-binding proteins; RAGE, receptor for advanced glycation end products.

where cerebral hypoperfusion and systemic inflammation play a role either as primary offenders or exacerbating factors. Other explanations regard CPB strategy (pH-stat, $\alpha$-stat), duration, and hypothermia/rewarming degree and speed. In addition, non-pulsatile flow, hemodilution, pressure autoregulation, anesthetic/cerebro-protective drugs, and the neuroimmune response to CPB can alter cerebral perfusion and metabolism [43-46].

The persistence of post-operative neurocognitive changes may be partially due to patient-specific risk factors rather than OHS-CPB procedures. This holds for stroke post-OHS incidence (about 1.2-5.7\%), which seems to be directly age-related, increasing every decade, and often associated with a medical history comprising the cardiovascular, kidney, respiratory and metabolic systems [46].

\section{CPB and neurological pattern in infants}

CHD are at high risk of intrauterine, neonatal and/or superimposed perioperative HI, contributing to global CNS dysmaturation [34, 36-42, 47]. Long-term neurocognitive and motor impairments are commonly diagnosed in the survivors, including poor impulse control, attention deficit, hyperactivity, mild language and cognitive deficit, and limited executive functioning ability. Although appearing outwardly normal, children with such deficits have poor academic performance and a lack of adult employability. They may also suffer high rates of depression and poor quality of life [48].

The issue that CNS damage due to OHS and CPB is mostly neither thrombotic nor hemorrhagic suggests that 
optimizing the hemodynamic parameters during CPB could significantly reduce the incidence of neurological deficits $[49,50]$. Apart from non-modifiable characteristics such as cardiac diagnosis, genetic anomalies, birthweight, prematurity, brain immaturity and gender [1-5], many other intra-operative-related temperature and flow-dependent factors potentially play a role in the development of neurological damage in infants. Among these, deep hypothermia circulatory arrest (DHCA), hypoperfusion, air emboli and systemic inflammatory response are the main causes [28, 30, 31, 50-64].

Altogether, it is possible to argue that there are significant differences in CPB management as well as in post-OHS CNS clinical patterns. The main ones regard the need in infants/children for extreme measures which are unnecessary in adults, such as DHCA, hemodilution, acid-base strategies, low perfusion pressures and wide variation of perfusion flow rates (Table 1). Nonetheless, smaller circulating blood volume, higher oxygen consumption rate, reactive pulmonary vascular bed, immature organ systems, and altered thermoregulation constitute differentiating factors explaining the different vulnerability to deleterious OHS-CPB effects in infants/children [50] (Table 1).

\section{CPB neuromonitoring}

The main target of the monitoring strategy is to reach and maintain an adequate cerebral perfusion during cardiovascular surgery, thereby preventing or minimizing neurological damage. Today, the most applied non-invasive neuromonitoring strategies include electroencephalography EEG or aEEG, TCD and NIRS [9-15, 65].

Table 1: Cardiopulmonary by-pass management comparison between adult and pediatric patients.

\begin{tabular}{lll}
\hline Parameter & Adult & Pediatric \\
\hline $\begin{array}{l}\text { Minimum CPB temperature, }{ }^{\circ} \mathrm{C} \\
\text { DHCA }\end{array}$ & $25-32$ & $15-25$ \\
Pump prime & Rare & Frequent \\
$\begin{array}{l}\text { Blood volume dilution, \% } \\
\text { Whole blood or } \mathrm{RBC} \text { support }\end{array}$ & $25-33$ & $100-300$ \\
Perfusion pressure, $\mathrm{mmHg}$ & Rare & Frequent \\
$\begin{array}{l}\text { Acid-base management strategy } \\
\text { Temperature, }{ }^{\circ} \mathrm{C}\end{array}$ & $50-80$ & $20-50$ \\
Glucose management & $\alpha-$-stat & pH-stat \\
$\begin{array}{l}\text { Hyperglycemia requiring insulin therapy } \\
\text { Hypoglycemia }\end{array}$ & $>28-30$ & $<28-30$ \\
\hline
\end{tabular}

CPB, cardiopulmonary by-pass; ${ }^{\circ} \mathrm{C}$, celsius; DHCA, deep hypothermic circulatory arrest; RBC, red blood cells; $\mathrm{Y}$, yes; N, no.

\section{EEG or aEEG}

\section{Pros}

EEG/aEEG provide useful information on large electrocortical activity areas, detecting subclinical seizures and confirming electrical silence during deep hypothermia $[9,10]$.

\section{Cons}

EEG/aEEG suffer from low resolution and cannot easily detect smaller areas of cortical ischemia. Hypothermia/DHCA and related therapeutic strategies such as anesthesia are the main bias for EEG/aEEG interpretation and experienced personnel are required [19].

\section{TCD}

Pros

TCD allows continuous and bilateral recordings of cerebral blood flow velocities through the major cerebral vessels during OHS-CPB phases. Decreased blood flow velocities in cerebral vessels have been associated with poor cognitive performance [11, 65] as well as high-intensity transient signals (HITS) which appear on the spectral envelope display to indicate an embolic event.

\section{Cons}

TCD monitoring requires an experienced team in order to limit several side-effects, such as HITS artifacts and the impossibility of differentiating gaseous from particulate emboli. In addition, other intra-operative issues such as constant probe position and sterile environment maintenance are limitations deserving consideration [19].

\section{NIRS \\ Pros}

NIRS provides non-invasive longitudinal monitoring of cerebral oximetry, function and hemodynamics. It detects hypoxia-ischemia insult during CPB associated CNS injury and later neurodevelopment [12-15, 66-68].

\section{Cons}

NIRS suffers from signal contamination from extracranial tissues and significant intra-patient and inter-patient 
variability in baseline regional cerebral oxygen saturation $\left(\mathrm{rcSO}_{2}\right)$ levels. Main limitations regard changes in the partial pressure of $\mathrm{CO}_{2}$ affecting the distribution of arterial and venous blood in the cranial vault, hemodilution, tissue edema, and skin pigmentation that may impact $\mathrm{rcSO}_{2}$ availability. Additional factors are related CPB-phases such as cooling/rewarming, DHCA and CPB duration [19].

Finally, on the basis of the aforementioned findings it is reasonable to argue that despite recent technological advances in neuromonitoring of patients who have undergone OHS-CPB, the possibility of detecting perioperative brain injury is an issue needing much further study.

\section{Biochemical markers}

The assessment of NB in biological fluids may provide an alternative, direct indicator of cell damage in the CNS when clinical, laboratory and radiological standard monitoring parameters are silent or unresponsive. They have the advantage of providing a quantitative indicator of the extent of brain lesions. More recently, FDA, EMA and NIH have voiced support for NB research. They encourage the integration of NB in drug development and their appropriate use in clinical practice by promoting NB qualification programs [16-18]. For example, in adults, as part of this process, new methods of assessing $\beta$-amyloid 1-42 and $t$-tau in the cerebrospinal fluid (CSF) of Alzheimer patients and of amyloid imaging using positron emission tomography have already been validated [69, 70]. Indeed, circulating cardiac Troponins T-I have been included in clinical guidelines as markers of cardiac morphologic damage [71] as well as glial fibrillary acidic protein (GFAP) and ubiquitin carboxyl-terminal hydrolase L1 in traumatic brain injury $[72,73]$.

In the perinatal period, the statements required by official institutions for validation of a NB in clinical guidelines are completely different than at adult age. In this regard, an optimality score for a NB has been defined that includes several criteria that need to be met as far as possible. In particular, the optimal NB should be: 1 . alternative and direct indicator of CNS damage when clinical and radiological assessments are still silent; 2 . early predictor of degree and location of injury; 3 . indicator of the extent of brain lesion; 4. marker of disease progression; 5 . well-studied in the pediatric population; 6. measurable worldwide by commercially available and easily reproducible kits; 7 . with an available range of reference for the pediatric population; 8. ability to be assessed in different biological fluids (CSF, blood, amniotic fluid, urine, saliva, milk) $[18,36,41,74-79]$.
Over the last few decades, NB such as oxidative stress markers, neuro and calcium binding proteins, inflammation biomarkers and vasoactive agents were evaluated as tools for prognostic evaluation in non-CHD/CHD infants and in the adult population [18, 36, 72-79].

Adenylate kinase, creatinine phosphokinase isoenzyme BB, lactate, myelin basic protein, S100B, neuronspecific enolase and glial fibrillary acidic protein are the main NB of interest in cardiac surgery [73, 80-84]. Results on their availability as early brain damage markers are encouraging, although several issues need to be overcome before their inclusion in daily practice [82].

Among several NB currently investigated in CNS monitoring, S100B protein seems to be one of the most promising NB of brain damage detection and prognosis both in adult, pediatric and newborn patients $[18,85,86]$. While in non-CHD patients the usefulness of S100B in brain monitoring has been proven, the history of the protein in CHD adults, children and infants showed a Gaussian-like trend: outstanding at first, followed by a dramatic decay and finally rehabilitated.

\section{S100B}

S100B is an acidic, calcium-binding protein of low molecular weight $(10.7 \mathrm{kDa})$, first identified by Moore as a protein fraction detectable in the CNS, particularly in glial and Schwann cells and in specific neuronal subpopulations [84-88]. The protein has a half-life of 30-60 min, and it is mostly eliminated by the kidney route (98\%) [89]. S100B is involved in intracellular signal transduction via protein phosphorylation inhibition, enzyme activity modulation, calcium homeostasis dysregulation, and affects cell morphology via interaction with cytoplasmic cytoskeleton elements [85-91]. At physiological concentrations (around $\mathrm{nM})$, the protein acts as a neurotrophic factor during neuronal development and regenerative processes [92-95]. Conversely, at high concentrations (sub-microM or microM), S100B manifests neurotoxic properties causing the cascade of pathophysiological events leading to cell apoptosis [85, 86, 95]. Recently, it has been suggested that S100B release occurs in isolated Schwann cells through a process that requires activation of the cell surface receptor, RAGE (receptor for advanced glycation end products). In particular, there is evidence that: i) S100B binds to the RAGE V-domain, ii) the high extracellular $\mathrm{Ca}^{2+}$ conditions might favor the formation of S100B multimers, and iii) S100B multimers cause RAGE dimerization or stabilization of preformed RAGE oligomers. Interestingly, at doses $\geq 500 \mathrm{nM}$ S100B up-regulates RAGE expression in neuronal cell lines due to 
RAGE-mediated reactive oxygen species (ROS) generation and the subsequent activation of MEK/ERK1/2 [93]. Therefore, these findings suggest that even at concentrations commonly thought to be protective towards neurons, S100B might turn neurotoxic in the presence of excess ROS generation.

\section{Further sources of S100B}

S100s are dimeric proteins constituting a major component of the cytosol of various cell types. A1B and BB dimers are mainly concentrated in the CNS. In detail, BB is mainly located in glial and Schwann cells but is also present in specific neuron sub-populations and in neural precursor cells $[85,86]$. A1B dimer is also concentrated in extranervous tissues such as white fat, skeletal muscle, heart, liver, spleen and kidney [85, 86, 96]. In this light, the possibility that extra-source sites of concentration of the protein could somewhat affect its reliability as a brain damage marker has been hypothesized. To this end, Haimoto et al. investigated the differential distribution of S100 A and B dimers in non-nervous human tissues. They showed that, of the total amount of S100B found in different tissues during the post-natal period, the highest concentration was in the brain $(538,000 \mu \mathrm{g}, 90.9 \%)$, followed by the muscles (42,000 $\mu \mathrm{g}, 7.1 \%)$, the adipocytes $(10,500 \mu \mathrm{g}, 1.77 \%)$, the heart $(1,000 \mu \mathrm{g}, 0.2 \%)$, and the liver $(200 \mu \mathrm{g}, 0.03 \%)$ [96]. Another S100B extra-source is the placenta: the protein has been shown, by immunohistochemistry, to be localized in villous and intermediate trophoblast cells of the normal placenta at various trimesters of gestation. Concentration of $\mathrm{S} 100 \mathrm{~B}$ in the placenta has been found to be gestational-agedependent [97-100].

Finally, S100B levels have been shown to reflect blood-brain barrier (BBB) integrity: changes in oxygen and carbon dioxide blood levels as well as metabolic CNS diseases can damage or change BBB permeability leading to a transport of the protein from brain to systemic circulation [101].

\section{S100B measurement techniques}

In the last few decades, many assays have been developed to improve detection of S100 protein in biological fluids: microcomplement fixation, radioimmuno, particle-counting, two-site immunoradioactive/IRMA (Sangtec 100, AD Sangtec Medical, Bromma, Sweden), immunoluminometric assay (Lia-mat Sangtec 100, AB Sangtec Medical, Bromma, Sweden) and ELISA (SynX Pharma, Toronto, Ontario, Canada).
Immunoluminometric assays are mainly used because of their qualities: they are rapid, reproducible, reliable and low-cost tests. Technological progress has improved the sensitivity of assays, whose threshold has decreased from 1.5 to $0.2 \mu \mathrm{g} / \mathrm{L}$ and lower than $0.02 \mu \mathrm{g} / \mathrm{L}$ by using chemiluminescence (Liaison S100, Dietzenbach, Germany) [102].

Currently Roche Diagnostics and DiaSorin, two companies specializing in in vitro diagnosis, have offered automated analyzers able to determine S100B protein concentration in serum. Roche Diagnostics' (Meylan, France) electrochemiluminescence immunoassay has shown a lower limit of protein detection of about $0.005 \mu \mathrm{g} / \mathrm{L}$, while by using DiaSorin assay the mean values are $27 \%$ higher than the former. Notably, both immunoassays can detect S100 dimers that contain S100B (S100BB and S100A1B) and provide a result within $18 \mathrm{~min}$ [103].

Recently bioMerieux Vidas (Marcy l'Etoile, France) has developed an automated enzyme-linked fluorescence assay with a lower threshold of $0.012 \mu \mathrm{g} / \mathrm{L}$, analysis time of approximately $20 \mathrm{~min}$ and the ability to detect both S100B dimers [102-105].

\section{S100B in adult OHS}

In Table 2 the main results of $\mathrm{S} 100 \mathrm{~B}$ pros and cons as a NB both in adults undergone to OHS and CPB are reported.

\section{Pros}

Preliminary studies showed a S100B perioperative pattern characterized by an increase in blood protein levels from the onset of $\mathrm{CPB}$, peaking at the end of the by-pass, and followed by a decline in the post-OHS period. In particular, a relationship has recently been observed between high S100B levels and post-OHS outcome, namely: i) short/long-term neurocognitive disorders with a sensitivity and specificity of 90\% [106], ii) stroke, also correlating with the extension of CNS damage [107], iii) a series of neurological phenomena including delirium, sleep disorders, memory loss and cognitive impairment up to 8 weeks post-OHS [107-111]. Finally, the length of hospital stay has also been correlated with high S100B post-OHS levels [112]. Based on the aforementioned findings, it has been suggested that S100B assessment in the first postoperative day might not only be a useful marker of post-OHS neurological complications but also a tool for evaluating the efficacy/side-effects of new OHS approaches and neuroprotective strategies [107-113]. This especially holds for other peri-OHS and patient parameters. The former, included a positive correlation between 
Table 2: Literature data on S100B patterns in adult patients undergone to open heart surgery and cardiopulmonary by-pass.

\begin{tabular}{|c|c|c|c|c|c|}
\hline Ref. & Study & $\mathbf{n}$ & Assay & $\mathbf{P} / \mathbf{C}$ & Main results \\
\hline [107] & PS & 20 & IRMA & $\mathrm{P}$ & $\begin{array}{l}\text { Higher } \mathrm{S} 100 \mathrm{~B} \text { at } 48 \mathrm{~h} \text { after surgery correlated with the size of infarcted } \\
\text { brain tissue and predicted median term survival. }\end{array}$ \\
\hline [108] & PS & 74 & LIA & $\mathrm{P}$ & $\begin{array}{l}\text { Higher postoperative S100B predicted early adverse neuropsycholog- } \\
\text { ical and neuropsychiatric outcome. }\end{array}$ \\
\hline [109] & PS & 45 & LIA & $\mathrm{P}$ & $\begin{array}{l}\text { Patients with elevated S100B values have more sleep disturbances } \\
\text { after cardiac surgery. }\end{array}$ \\
\hline [110] & PS & 130 & IRMA & $\mathrm{P}$ & $\begin{array}{l}\text { Higher S100B correlated with age, CPB duration bypass time and with } \\
\text { impaired memory performance. }\end{array}$ \\
\hline [111] & PS & 100 & LIA & $\mathrm{C}$ & No correlation between S100B and long-term cognitive impairment. \\
\hline [115] & PS & 32 & LIA & $C$ & $\begin{array}{l}\text { Lower perioperative } \mathrm{S} 100 \mathrm{~B} \text { levels in adults undergone to OHS without } \\
\text { CPB than those with CPB. }\end{array}$ \\
\hline [116] & PS & 132 & IRMA & C & $\begin{array}{l}\text { Higher postoperative } \mathrm{S} 100 \mathrm{~B} \text { from the surgical field and in the shed } \\
\text { mediastinal blood. Autotransfusion interferes S100B availability as } \\
\text { brain damage marker. }\end{array}$ \\
\hline [117] & PS & 20 & LIA & $C$ & $\begin{array}{l}\text { Six-fold reduced S100B peak levels in the cell saving device group } \\
\text { compared to the cardiotomy suction group. }\end{array}$ \\
\hline [118] & PS & 30 & LIA, ELISA & $C$ & $\begin{array}{l}\text { S100A1B and S100BB analysis did not distinguish S100B cerebral } \\
\text { from extracerebral sources in mediastinal blood. }\end{array}$ \\
\hline [119] & $M$ & 411 & & $C$ & $\begin{array}{l}\text { Off-pump and on-pump CABG surgeries increase } \mathrm{S} 100 \mathrm{~B} \text { in adult } \mathrm{CHD} \\
\text { patients within } 24 \mathrm{~h} \text { after on-pump CABG surgery. }\end{array}$ \\
\hline [120] & PS & 10 & LIA & C & $\begin{array}{l}\text { Increased serum S100B levels due to protein's mediastinal extra- } \\
\text { source. }\end{array}$ \\
\hline [121] & PS & 21 & LIA & $C$ & $\begin{array}{l}\text { Early increase in } \mathrm{S} 100 \mathrm{~B} \text { correlated with markers of tissue injury outside } \\
\text { the brain. }\end{array}$ \\
\hline [122] & PS & 40 & LIA & $C$ & $\begin{array}{l}\text { Both intravenous UFH and subcutaneous LMWH administration induces } \\
\text { increases in serum S100 concentration. }\end{array}$ \\
\hline [123] & $M$ & 549 & & $\mathrm{C}$ & $\begin{array}{l}\text { Lower } \mathrm{S} 100 \mathrm{~B} \text { in the inhalation anesthesia group than in the TIVA group } \\
\text { after CPB and } 24 \mathrm{~h} \text { after surgery. }\end{array}$ \\
\hline [124] & PS & 50 & ELISA & $C$ & $\begin{array}{l}\text { S100B levels correlated with severe insulin resistance and stress } \\
\text { hyperglycemia. }\end{array}$ \\
\hline
\end{tabular}

Ref., references; $n$, number; P, pros; C, cons; PS, prospective study; IRMA, immunoradiometric assay; LIA, luminescence immunoassay; CPB, cardiopulmonary bypass; OHS, open heart surgery; ELISA, enzyme-linked immunosorbent assays; $M$, metanalysis; CABG, coronary artery bypass graft surgery; CHD, congenital heart disease; UFH, unfractionated heparin; LMWH, low molecular weight heparin; TIVA, total intravenous anesthesia.

S100B and the duration of aortic cross-clamping, of DHCA, and of occurrence of cerebral emboli $[107,112,114$, 115]. The latter with pre-existing patient specific factors such as age, cerebrovascular complications, and renal impairment. This finding is noteworthy bearing in mind that the protein's concentrations are age-dependent [113].

\section{Cons}

Initial confidence in the correlation between S100B and brain damage has faded over the years following the demonstration that some early increases in serum protein levels may reveal the presence of an extra-cerebral S100B origin [115-118]. One of the main reasons may reside in the measurement of the protein during the use of new specific surgical devices such as a filter in the arterial line or heparin-coated surfaces and new OHS phases including the on-off-pump phase $[114,116]$. Furthermore, the introduction of autotransfusion and mediastinal shed blood has been found to influence the S100B release from CPB phase up to $10 \mathrm{~h}$ post-OHS [116]. Moreover, cardiotomy suction has been suggested as a bias factor in increased S100B release during CPB [117].

The effects of surgical procedure deserve further consideration. These mainly regarded the absence of any perioperative S100B differences between: i) patients who had undergone OHS using a cell-saving device with CPB and in those operated on off-pump [119] ii) samples collected from pleural drainage of patients having a thoracotomy without $\mathrm{CPB}$ and those collected from mediastinal drains with CPB [120].

The effects of the different sites of sampling have been found to affect S100B reliability as a brain damage marker. In particular, higher protein levels (up to 1,000 times) 
detected in blood from surgical wounds, bone marrow aspirate, and from traumatized mediastinal fat and skeletal muscle did not make it possible to distinguish cerebral from extracerebral origin of S100B. Authors concluded that an early increase in S100B resulted from extra-cerebral contamination, while a late increase (after 24-48 h) of S100B correlated with brain damage $[118,121]$. However, the aforementioned confounding factors have been partly overcome by using a cardiotomy reservoir, thus reducing the total amount of extra-source protein.

Lastly, perioperative therapeutic strategies sideeffects on S100B releasing in the systemic circulation has to be considered. This holds for unfractionated heparin and low molecular weight heparin administration routinely used for venous thromboembolism prophylaxis in OHS patients in which an increase of the total amount of S100 proteins members including at least one S100B monomer has been found [122]. This result could be due to heparin anti-inflammatory action via inhibition of S100 binding to RAGE [122].

Finally, anesthesia methods and glucose metabolic impairment have been found to interfere with S100B release $[123,124]$. In detail, lower S100B levels have been found in patients subjected to generally inhaled rather than intravenous anesthesia, suggesting a brain protecting role [123]. Conversely, hyperglycemia led to higher S100B levels, indicating insulin-resistance and stress hyperglycemia as enhancers of OHS brain injury in these patients [124].

\section{S100B in infants and children OHS}

In Table 3 the main results of $\mathrm{S} 100 \mathrm{~B}$ pros and cons as a NB both in adults undergone to OHS and CPB are reported.

\section{Pros}

Following the observations on adults, S100B has been assessed in CHD infants subjected to OHS to monitor brain stress in different perioperative phases. In particular, studies evaluating CNS stress during OHS showed significantly higher protein levels: i) either before or after the end of surgical procedure [41]; ii) during and after OHS in infants complicated by early perioperative death and/or brain damage [41, 125-128] when compared to infants without perioperative complications; iii) as an index of increased cerebrovascular resistance and of changes in cerebral oxygen saturation by means of NIRS perioperative

Table 3: Literature data on S100B patterns in congenital heart diseases infants undergone to open heart surgery and cardiopulmonary bypass.

\begin{tabular}{|c|c|c|c|c|c|}
\hline Ref. & Study & $\mathbf{n}$ & Assay & $\mathrm{P} / \mathrm{C}$ & Main results \\
\hline [125] & RS & 75 & LIA & $\mathrm{P}$ & $\begin{array}{l}\text { Perioperative S100B z-scores were significantly higher in the cases } \\
\text { developing neurological deficits. }\end{array}$ \\
\hline [128] & PS & 32 & IRMA & $\mathrm{P}$ & $\begin{array}{l}\text { A significant correlation between } \mathrm{S} 100 \mathrm{~B} \text { and increased cerebrovascu- } \\
\text { lar resistance. }\end{array}$ \\
\hline [129] & PS & 18 & ELISA & $\mathrm{P}$ & $\begin{array}{l}\text { Higher S100B in the perioperative period (particularly CPB) in cases } \\
\text { with a wide cerebral arteriovenous difference measured by NIRS. }\end{array}$ \\
\hline [130] & PS & 109 & LIA & $\mathrm{P}$ & $\begin{array}{l}\text { Perioperative } \mathrm{S} 100 \mathrm{~B} \text { inversely correlated with the size of the ascending } \\
\text { aorta in hypoplastic left heart syndrome and suggested as a marker for } \\
\text { pre-existing brain injury and mortality. }\end{array}$ \\
\hline [131] & $\mathrm{CCS}$ & 48 & LIA & $\mathrm{P}$ & Higher S100B concentrations in CHD cyanotic infants. \\
\hline [132] & PS & 43 & LIA & $\mathrm{P}$ & $\begin{array}{l}\text { Higher } \mathrm{S} 100 \mathrm{~B} \text { in } \mathrm{CHD} \text { cyanotic infants undergone to uncontrolled } \\
\text { hyperoxic reoxygenation in the rewarming-CPB phase. }\end{array}$ \\
\hline [134] & RCT & 79 & ELISA & $P$ & $\begin{array}{l}\text { Controlled reoxygenation rewarming-CPB phase significantly } \\
\text { decreased S100B levels in CHD infants (single-ventricle). }\end{array}$ \\
\hline [137] & $\mathrm{RCT}$ & 67 & ELISA & $P$ & $\begin{array}{l}\text { S100B significantly differed between the normoxic and hyperoxic } \\
\text { groups at different CPB phases. }\end{array}$ \\
\hline [139] & PS & 90 & LIA & $C$ & $\begin{array}{l}\text { Higher } \mathrm{S} 100 \mathrm{~B} \text { in pleural, pericardial and peritoneal fluids before and } \\
\text { after cardiac surgery in CHD infants. }\end{array}$ \\
\hline [144] & PS & 26 & LIA & $P$ & $\begin{array}{l}\text { In CHD infants } \mathrm{S} 100 \mathrm{~B} \text { protein is not affected by an adipose tissue extra- } \\
\text { source release. }\end{array}$ \\
\hline [145] & $\mathrm{RCT}$ & 60 & LIA & $\mathrm{P}$ & $\begin{array}{l}\text { Higher } \mathrm{S} 100 \mathrm{~B} \text { in the phentolamine-treated group than in controls from } \\
\text { the rewarming-CPB phase up to } 12 \mathrm{~h} \text { from surgery. }\end{array}$ \\
\hline
\end{tabular}

Ref., references; $n$, number; P, pros; C, cons; RS, retrospective study; LIA, luminescence immunoassay; PS, prospective study; IRMA, immunoradiometric assay; ELISA, enzyme-linked immunosorbent assay; CPB, cardiopulmonary by-pass; NIRS, near infrared spectroscopy; CCS, case-control study; CHD, congenital heart disease; RCT, randomized control study; h, hours. 
Table 4: Food and Drugs Administration and European Medicine Agency criteria for perinatal neuro-biomarkers inclusion in clinical guidelines. Comparison between adult and pediatric obtained results.

\begin{tabular}{llrlr}
\hline S100B & Adults & Ref. & Infants & Ref. \\
\hline Indicator of CNS damage & $Y$ & {$[81,101,106,114]$} & $Y$ & {$[74,105,125,126]$} \\
Degree of injury & $Y$ & {$[81,114]$} & $Y$ & {$[105,125,126,131,132]$} \\
Lesion extension & $Y$ & {$[106,107]$} & $Y$ & {$[74,125,126]$} \\
Longitudinal monitoring & $Y$ & {$[106-113]$} & $Y$ & {$[75-79,84,85,98,99,127-129]$} \\
Pediatric/adult population & $Y$ & {$[106]$} & $Y$ & {$[106]$} \\
Available kits & $Y$ & {$[102-105]$} & $Y$ & {$[102-105]$} \\
Reference range & $Y$ & {$[147]$} & $Y$ & {$[36]$} \\
Biological fluid & CSF, PB & {$[147]$} & CSF, PB, AF, CB, U, S, M & {$[36,75-79,84,85,98,99]$} \\
\hline
\end{tabular}

CNS, central nervous system; Y, yes; CSF, cerebrospinal fluid; PB, peripheral blood; AF, amniotic fluid; CB, cord blood; U, urine; S, saliva; $M$, milk.

monitoring, particularly the rewarming phase [129], iv) in cyanotic CHD infants when compared to non-cyanotic CHD because of their increased chance of brain stress/damage perioperative exposure [130,131], and v) in infants who had undergone $\mathrm{CPB}$ weaning with or without the controlled rewarming re-oxygenation strategy [132-136]. The neuroprotective action of re-oxygenation has been confirmed by a lower S100B release in systemic circulation both in animal models and in cyanotic CHD infants [133-138]. Altogether, it is reasonable to argue for the usefulness of S100B as a predictor of brain distress/damage as well as of a potentially fatal outcome.

\section{Cons}

Despite the aforementioned promising results, the fate of S100B as a diagnostic tool of CNS damage in the perioperative period of CHD infants is still controversial and debated. As for adults the protein was progressively abandoned for CNS monitoring in CHD children due to a putative extrasource of protein bias [118, 139-143]. This especially refers to its potential release from cardiac adipose tissue during $\mathrm{CPB}$ phases [140, 143]. Another non-neural S100B source might be the pericardial fluid in which the protein has been measured in CHD children during OHS [139]. Finally, further studies aimed at investigating the adoption of new cardiotomy reservoirs and of controlled re-oxygenation effects on S100B release are needed in pediatric patients.

\section{Conclusions}

Today, as for non-CHD high risk infants a trustable NB able to predict perioperative brain damage in CHD children is still eagerly awaited. At this stage, there are no clinical protocols or guidelines approved by FDA, NIH or by the
EMA validating S100B assessment in CHD children as for traumatic brain injury. The issue is noteworthy taking into consideration the lack of studies in children and particularly in adults fulfilling the items requested by FDA, EMA and NIH (Table 4).

Before answering the question: "Does $\mathrm{S1OOB}$ behave as a friend or an enemy in the management of OHS?" the following confounding points affecting the protein's reliability as a predictor of CNS damage need to be addressed:

(1) A clear dichotomy has to be taken into account between adult and pediatric patients. The main differences regard: i) the diseases subjected to surgical treatment (acquired vs. congenital) [1-4, 5], ii) CPB strategy (pH vs. $\alpha$-stat) [50], iii) degree of CPB length, the need of hypothermia and of DHCA that are not often necessary for adults, iv) clinical history characterized by most common pre-OHS medical conditions affecting cardiovascular, metabolic, renal and CNS systems instead of pre-existing multiorgan congenital/genetic disorders $[1-4,46]$, and iv) adults vs. children multiorgan adaptation to CPB widely accepted as a deliberate hypoxicischemic reperfusion damage representing the price to pay during OHS repair. This especially refers to different pediatric cardiovascular and cerebrovascular anatomical and physiological characteristics in terms of immaturity, smaller circulating blood volume and higher oxygen consumption rate [50].

(2) The design of the trials themselves in terms of small cohort sizes, lack of multicenter investigations, heterogeneity of neurological complications and of CHD investigated (cyanotic, non-cyanotic).

(3) The operator-dependent heterogeneity of OHS techniques varying from center to center, which can surely affect S100B reliability.

(4) The advances in the devices and strategies recently used for CPB performance (cardiotomy reservoir, controlled 
re-oxygenation, on-off pump) that can constitute a bias in the evaluation of S100B reliability as a perioperative CNS damage diagnostic test.

(5) Previous data on the presence of non-neural S100B sources, in adults and children who have undergone OHS, thus affecting the reliability of the protein as a brain damage marker warrants further consideration. The main issue regards the release of S100B from adipose tissue under different perioperative conditions and sites of concentration such as: sternotomy, on-off-pump phase, autotransfusion and shed mediastinal blood, cardiotomy suction, thoracic and pericardial drainage [117, 121]. However, no data, at this time, have been provided regarding the measurement of the amount of adipose tissue released during OHS either in adults or pediatric patients. The issue is of relevance bearing in mind that, in the absence of any related endocrine disorder, the total amount of adipose tissue is agerelated and significantly higher in children than in adults. Notably, the absence of any difference in blood levels of a well-established biomarker of circulating adipose tissue such as adiponectin, in CHD, OHS-CPB treated children, offers additional information on the present controversial and debated issue [144]. It is noteworthy, in this respect, that other intra-operatory events can be related to an exaggerated S100B release in systemic circulation such as: i) hypoxia-hyperoxia insults occurring during $\mathrm{CPB}$ cooling and rewarming phases [128, 129], ii) changes in brain blood barrier permeability temperature and CPB-management-dependent techniques (anesthesia, on-off pump, DHCA) [82, 83, 139], and iii) cyanotic or non-cyanotic CHD [128]. Altogether, taking into consideration that adipose tissue accounts for $1.77 \%$ of the total amount of S100B, the possibility that during OHS and CPB it could somewhat affect S100B level in systemic circulation, and its reliability as brain damage marker is remote.

(6) Different protein assessment techniques and assays performed in the studies herein reported, each of which measured S100 BB or A1B dimers, deserve further discussion. The issue is noteworthy since A1B dimer is not brain tissue-specific but is also concentrated in extra-nervous tissues (i.e.: white fat, skeletal muscle, heart, liver, spleen and kidney) [88, 89, 103-106, 146]. In conclusion, the present overview supports the notion that S100B protein assessment in biological fluids of patients who have undergone OHS and CPB could be a useful diagnostic tool of perioperative CNS stress and damage. Further studies measuring contemporary adiponectin and S100B protein in carefully selected study populations are needed to shed further light on this currently much-debated and controversial issue.

Research funding: The authors declare that they have no known competing financial interests or personal relationships, which have or could be perceived to have influenced the work reported in this article. This work is part of the Italia-Olanda (I.O.) PhD International Program under the auspices of the Italian Society of Neonatology and was partially supported by grants to Diego Gazzolo from "I Colori della Vita Foundation", Italy.

Author contributions: Giuseppe Lapergola, Alessandro Graziosi, Ebe D’Adamo, Patrizia Brindisino, Mariangela Ferrari, Anna Romanelli, Mariachiara Strozzi, Roberta Libener, Danilo AW Gavilanes, Antonio Maconi, Angela Satriano, Alessandro Varrica and Diego Gazzolo made substantial contribution to conception and design of the study, acquisition, analysis, and interpretation of data; authors participate in drafting the article or revising it critically. All authors have accepted responsibility for the entire content of this manuscript and approved its submission.

Competing interests: Authors state no conflict of interest. Informed consent: Not applicable.

Ethical approval: Research involving human subjects complied with all relevant national regulations, institutional policies and is in accordance with the tenets of the Helsinki Declaration (as revised in 2013). The Local Ethic Committees of the Institutions approved the study protocol.

\section{References}

1. Moodie DS. The global burden of cardiovascular disease. Congenit Heart Dis 2016;11:213.

2. Rao PS. Congenital heart defects: a review. In: Rakel RE, editor. Congenital heart defects: selected aspects. Conn's current therapy. Philadelphia, PA: W.B. Saunders; 2010:213 p.

3. Dolk H, Loane M, Garne E. Congenital heart defects in Europe: prevalence and perinatal mortality, 2000-2005. Circulation 2011;123:841-9.

4. Richards AA, Garg V. Genetics of congenital heart disease. Curr Cardiol Rev 2010;6:91-7.

5. Bernier PL, Stefanescu A, Samoukovic G, Tchervenkov Cl. The challenge of congenital heart disease worldwide: epidemiologic and demographic facts. Semin Thorac Cardiovasc Surg Pediatr Card Surg Annu 2010;13:26-34.

6. Jacobs JP, He X, Mayer JE, Austin EH 3rd, Quintessenza JA, Karl TR, et al. Mortality trends in pediatric and congenital heart surgery: an analysis of the society of thoracic surgeons congenital heart surgery database. Ann Thorac Surg 2016;102: 1345-52.

7. Dolk H, Loane M, Garne E. The prevalence of congenital anomalies in Europe. Adv Exp Med Biol 2010;686:349-64. 
8. Garne E, Khoshnood B, Loane M, Boyd P, Dolk H, EUROCAT Working Group. Termination of pregnancy for fetal anomaly after 23 weeks of gestation: a European register-based study. BJOG 2010;117:660-6.

9. Miller G, Rodichok LD, Baylen BG, Myers JL. EEG changes during open heart surgery on infants aged six months or less: relationship to early neurologic morbidity. Pediatr Neurol 1994; 10:124-30.

10. Isley MR, Edmonds HL Jr., Stecker M. Guidelines for intraoperative neuromonitoring using raw (analog or digital waveforms) and quantitative electroencephalography: a position statement by the American Society of Neurophysiological Monitoring. J Clin Monit Comput 2009;23: 369-90.

11. Truemper EJ, Fischer AZ. Cerebrovascular developmental anatomy and physiology in the infant and child. In: Babikian VL, Wechsler LR, editors. Transcranial Doppler ultrasonography. St. Louis: Mosby; 1993:355-75 pp.

12. Ramamoorthy C, Tabbutt S, Kurth CD, Steven JM, Montenegro LM, Durning S, et al. Effects of inspired hypoxic and hypercapnic gas mixtures on cerebral oxygen saturation in neonates with univentricular heart defects. Anesthesiology 2002;96:283-8.

13. Daubeney PE, Smith DC, Pilkington SN, Lamb RK, Monro JL, Tsang VT, et al. Cerebral oxygenation during paediatric cardiac surgery: identification of vulnerable periods using near infrared spectroscopy. Eur J Cardio Thorac Surg 1998;13:370-7.

14. Kurth CD, Steven JM, Nicolson SC. Cerebral oxygenation during pediatric cardiac surgery using deep hypothermic circulatory arrest. Anesthesiology 1995;82:74-82.

15. Ranucci M, Isgrò G, De la Torre T, Romitti F, Conti D, Carlucci C. Near-infrared spectroscopy correlates with continuous superior vena cava oxygen saturation in pediatric cardiac surgery patients. Paediatr Anaesth 2008;18:1163-9.

16. Califf RM. Biomarker definitions and their applications. Biol Med 2018;243:213-21.

17. Manolis E, Koch A, Deforce D, Vamvakas S. The European Medicines Agency experience with biomarker qualification. Methods Mol Biol 2015;1243:255-72.

18. Serpero LD, Bellissima V, Colivicchi M, Sabatini M, Frigiola A, Ricotti A, et al. Next generation biomarkers for brain injury. J Matern Fetal Neonatal Med 2013;S2:44-9.

19. Harvey RE. Neurological outcomes and neuromonitoring in cardiac surgery. Int Anesthesiol Clin 2018;56:21-46.

20. Kim HJ, Tsao JW, Stanfill AG. The current state of biomarkers of mild traumatic brain injury. Insight 2018;11:e97105.

21. Undén J, Dalziel SR, Borland ML, Phillips N, Kochar A, Lyttle MD, et al. External validation of the Scandinavian guidelines for management of minimal, mild and moderate head injuries in children. Paediatric Research in Emergency Departments International Collaborative (PREDICT). BMC Med 2018;16: 176-86.

22. Ailawadi G, Zacour RK. Cardiopulmonary bypass/extracorporeal membrane oxygenation/left heart bypass: indications, techniques, and complications. Surg Clin North Am 2009;89: 781-96.

23. Meyer DB, Jacobs JP, Hill K, Wallace AS, Bateson B, Jacobs ML. Variation in perfusion strategies for neonatal and infant aortic arch repair: contemporary practice in the STS congenital heart surgery database. World J Pediatr Congenit Heart Surg 2016;7: 638-44.
24. Algra SO, Jansen NJ, van der Tweel I, Schouten AN, Groenendaal F, Toet $M$, et al. Neurological injury after neonatal cardiac surgery: a randomized, controlled trial of two perfusion techniques. Circulation 2014;129:224-33.

25. Sahu B, Chauhan S, Kiran U, Bisoi A, Lakshmy R, Selvaraj T, et al. Neurocognitive function in patients undergoing coronary artery bypass graft surgery with cardiopulmonary bypass: the effect of two different rewarming strategies. J Cardiothorac Vasc Anesth 2009;23:14-21.

26. Misfeld M, Leontyev S, Borger MA, Gindensperger O, Lehmann S, Legare JF, et al. What is the best strategy for brain protection in patients undergoing aortic arch surgery? A single center experience of 636 patients. Ann Thorac Surg 2012;93:1502-8.

27. Aneman A, Brechot N, Brodie D, Colreavy F, Fraser J, Gomersall C, et al. Advances in critical care management of patients undergoing cardiac surgery. Intensive Care Med 2018;44: 799-810.

28. Rubens FD, Mesana T. The inflammatory response to cardiopulmonary bypass: a therapeutic overview. Perfusion 2004;19:S5-12.

29. Nollert G, Reichart B. Cardiopulmonary bypass and cerebral injury in adults. Shock 2001;16 S1:16-9.

30. Kerendi F, Halkos ME, Kin H. Up-regulation of hypoxia inducible factor is associated with attenuation of neuronal injury in neonatal piglets undergoing deep hypothermic circulatory arrest. J Thorac Cardiovasc Surg 2005;130:1079-84.

31. Heyer EJ, Lee KS, Manspeizer HE. Heparin-bonded cardiopulmonary bypass circuits reduce cognitive dysfunction. J Cardiothorac Vasc Anesth 2002;16:37-44.

32. Chen J, Zimmerman RA, Jarvik GP, Nord AS, Clancy RR, Wernovsky $\mathrm{G}$, et al. Perioperative stroke in infants undergoing open heart operations for congenital heart disease. Ann Thorac Surg 2009;88:823-9.

33. Shann KG, Likosky DS, Murkin JM, Baker RA, Baribeau YR, DeFoe $G R$, et al. An evidence-based review of the practice of cardiopulmonary bypass in adults: a focus on neurologic injury, glycemic control, hemodilution, and the inflammatory response. J Thorac Cardiovasc Surg 2006;132:283-90.

34. Barkhuizen M, Abella R, Vles JSH, Zimmermann LJI, Gazzolo D, Gavilanes AWD. Antenatal and perioperative mechanisms of global neurological injury in congenital heart disease. Pediatr Cardiol 2021;42:1-18.

35. Butler J, Rocker GM, Westaby S. Inflammatory response to cardiopulmonary bypass. Ann Thorac Surg 1993;55:552-9.

36. Bersani I, Pluchinotta F, Dotta A, Savarese I, Campi F, Auriti C, et al. Early predictors of perinatal brain damage: the role of neurobiomarkers. Clin Chem Lab Med 2020;58:471-86.

37. Inder TE, Volpe JJ. Mechanisms of perinatal brain injury. Semin Neonatol 2000;5:3-16.

38. Lorek A, Takei Y, Cady EB, Wyatt JS, Penrice J, Edwards AD, et al. Delayed ("secondary") cerebral energy failure after acute hypoxia-ischemia in the newborn piglet: continuous 48-h studies by phosphorus magnetic resonance spectroscopy. Pediatr Res 1994;36:699-706.

39. Johnston MV, Trescher WH, Ishida A, Nakajima W. Neurobiology of hypoxic-ischemic injury in the developing brain. Pediatr Res 2001;49:735-41.

40. Salford LG, Plum F, Siesjö BK. Graded hypoxia-oligemia in rat brain. I. Biochemical alterations and their implications. Arch Neurol 1973;29:227-33. 
41. Abella R, Varrica A, Satriano A, Tettamanti G, Pelissero G, Gavilanes $A D$, et al. Biochemical markers for brain injury monitoring in children with or without congenital heart diseases. CNS Neurol Disord Drug Targets 2015;14:12-23.

42. Hassell KJ, Ezzati M, Alonso-Alconada D, Hausenloy DJ, Robertson NJ. New horizons for the newborn brain protection: enhancing endogenous neuroprotection. Arch Dis Child Fetal Neonatal Ed 2015;100:F541-2.

43. O'Dwyer C, Prough DS, Johnston WE. Determinants of cerebral perfusion during cardiopulmonary bypass. I Cardiothorac Vasc Anesth 1996;10:54-64.

44. Selnes OA, Gottesman RF, Grega MA, et al. Cognitive and neurologic outcomes after coronary-artery bypass surgery. $\mathrm{N}$ Engl J Med 2012;366:250-7.

45. Miatton M, De Wolf D, François K, Thiery E, Vingerhoets G. Neurocognitive consequences of surgically corrected congenital heart defects: a review. Neuropsychol Rev 2006;16:65-85.

46. Mc Donagh DL. Neurologic complications of cardiac surgery. Lancet Neurol 2014;13:490-502.

47. Claessens NHP, Algra SO, Ouwehand TL, Jansen NJG, Schappin $R$, Haas F, et al. Perioperative neonatal brain injury is associated with worse school-age neurodevelopment in children with critical congenital heart disease. Dev Med Child Neurol 2018;60: 1052-8.

48. Gaynor JW, Stopp C, Wypij D, Andropoulos DB, Atallah J, Atz AM, et al. Neurodevelopmental outcomes after cardiac surgery in infancy. Pediatrics 2015;135:816-25.

49. Raissadati A, Nieminen H, Jokinen E, Sairanen H. Progress in late results among pediatric cardiac surgery patients: a populationbased six-decade study with $98 \%$ follow-up. Circulation 2015; 131:347-53.

50. Dönmez A, Yurdakök 0. Cardiopulmonary bypass in infants. J Cardiothorac Vasc Anesth 2014;28:778-88.

51. Arrica M, Bissonnette B. Therapeutic hypothermia. Semin Cardiothorac Vasc Anesth 2007;11:6-15

52. Ren Z, Ding W, Su Z, Gu X, Huang H, Liu J, et al. Mechanisms of brain injury with deep hypothermic circulatory arrest and protective effects of coenzyme Q10. J Thorac Cardiovasc Surg 1994;108:126-33.

53. Kawata H, Fackler JC, Aoki M, Tsuji MK, Sawatari K, Offutt M, et al. Recovery of cerebral blood flow and energy state in piglets after hypothermic circulatory arrest vs. recovery after low-flow bypass. J Thorac Cardiovasc Surg 1993;106:671-85.

54. Berliocchi L, Bano D, Nicotera P. Ca ${ }^{2+}$ signals and death programmes in neurons. Philos Trans R Soc Lond B Biol Sci 2005;360:2255-8.

55. De Somer F. Impact of oxygenator characteristics on its capability to remove gaseous microemboli. J Extra Corpor Technol 2007;39:271-3.

56. Taylor RL, Borger MA, Weisel RD, Fedorko L, Feindel CM. Cerebral microemboli during cardiopulmonary bypass: increased emboli during perfusionist interventions. Ann Thorac Surg 1999;68: 89-93.

57. Geissler HJ, Allen SJ, Mehlhorn U, Davis KL, de Vivie ER, Kurusz $M$, et al. Cooling gradients and formation of gaseous microemboli with cardiopulmonary bypass: an echocardiographic study. Ann Thorac Surg 1997;64:100-4.

58. Prasongsukarn K, Borger MA. Reducing cerebral emboli during cardiopulmonary bypass. Semin Cardiothorac Vasc Anesth 2005;9:153-8.
59. Simon NP. Long-term neurodevelopmental outcome of asphyxiated newborns. Clin Perinatol 1999;26:767-78.

60. Crack PJ, Taylor JM. Reactive oxygen species and the modulation of stroke. Free Radic Biol Med 2005;38:1433-44.

61. Alcaraz AJ, Manzano L, Sancho L, Vigil MD, Esquivel F, Maroto E, et al. Different proinflammatory cytokine serum pattern in neonate patients undergoing open heart surgery. Relevance of IL-8. J Clin Immunol 2005;25:238-45.

62. Ashraf S, Tian Y, Cowan D, Entress A, Martin PG, Watterson KG. Release of proinflammatory cytokines during pediatric cardiopulmonary bypass: heparin-bonded vs. nonbonded oxygenators. Ann Thorac Surg 1997;64:1790-4.

63. Shum-Tim D, Tchervenkov Cl, Jamal AM, Nimeh T, Luo CY, Chedrawy $\mathrm{E}$, et al. Systemic steroid pretreatment improves cerebral protection after circulatory arrest. Ann Thorac Surg 2001;72:1465-71.

64. El Azab SR, Rosseel PM, de Lange JJ, Groeneveld AB, van Strik R, van Wijk EM, et al. Dexamethasone decreases the pro- to antiinflammatory cytokine ratio during cardiac surgery. Br J Anaesth 2002;88:496-501.

65. Bakker MJ, Hofmann J, Churches OF, Badcock NA, Kohler M, Keage HA. Cerebrovascular function and cognition in childhood: a systematic review of transcranial Doppler studies. BMC Neurol 2014;14:43-55.

66. Hagino I, Anttila V, Zurakowski D, Duebener LF, Lidov HG, Jonas RA. Tissue oxygenation index is a useful monitor of histologic and neurologic outcome after cardiopulmonary bypass in piglets. J Thorac Cardiovasc Surg 2005;130:384-92.

67. Hoffman GM, Brosig CL, Mussatto KA, Tweddell JS, Ghanayem NS. Perioperative cerebral oxygen saturation in neonates with hypoplastic left heart syndrome and childhood neurodevelopmental outcome. J Thorac Cardiovasc Surg 2013; 146:1153-64.

68. Morimoto Y, Niida Y, Hisano K, Hua Y, Kemmotsu O, Murashita T, et al. Changes in cerebral oxygenation in children undergoing surgical repair of ventricular septal defects. Anaesthesia 2003; 58:77-83.

69. Blennow K, Zetterberg H. Biomarkers for Alzheimer's disease: current status and prospects for the future. J Intern Med 2018; 284:643-63.

70. Park JC, Han SH, Yi D, Byun MS, Lee JH, Jang S, et al. Plasma tau/ amyloid-beta1-42 ratio predicts brain tau deposition and neurodegeneration in Alzheimer's disease. Brain 2019;142: 771-86.

71. Pulkki K, Suvisaari J, Collinson P, Ravkilde J, Stavljenic-Rukavina A, Hammerer-Lercher A, et al. A pilot survey of the use and implementation of cardiac markers in acute coronary syndrome and heart failure across Europe. The CARdiac MArker Guideline Uptake in Europe (CARMAGUE) study. Clin Chem Lab Med 2009; 47:227-34.

72. Bazarian JJ, Biberthaler P, Welch RD, Lewis LM, Barzo P, BognerFlatz V, et al. Serum GFAP and UCH-L1 for prediction of absence of intracranial injuries on head CT (ALERT-TBI): a multicentre observational study. Lancet Neurol 2018;17:782-9.

73. Thelin E, Al Nimer F, Frostell A, Zetterberg H, Blennow K, Nyström $H$, et al. A serum protein biomarker panel improves outcome prediction in human traumatic brain injury. J Neurotrauma 2019; $36: 2850-62$

74. Gazzolo D, Grutzfeld D, Michetti F, Toesca A, Lituania M, Bruschettini $M$, et al. Increased S100B in cerebrospinal fluid of 
infants with bacterial meningitis: relationship to brain damage and routine cerebrospinal fluid findings. Clin Chem 2004;50: 941-4.

75. Gazzolo D, Masetti P, Meli M, Grutzfeld D, Michetti F. Elevated S100B protein as an early indicator of intracranial haemorrhage in infants subjected to extracorporeal membrane oxygenation. Acta Paediatr 2002;91:218-21.

76. Gazzolo D, Bruschettini M, Corvino V, Oliva R, Sarli R, Lituania M, et al. S100b protein concentrations in amniotic fluid correlate with gestational age and with cerebral ultrasound scanning results in healthy fetuses. Clin Chem 2001;47:954-6.

77. Gazzolo D, Florio P, Ciotti S, Marinoni E, di lorio R, Bruschettini $M$, et al. S100B protein in urine of preterm newborns with ominous outcome. Pediatr Res 2005;58:1170-4.

78. Gazzolo D, Lituania M, Bruschettini M, Ciotti S, Sacchi R, Serra G, et al. S100B protein levels in saliva: correlation with gestational age in normal term and preterm newborns. Clin Biochem 2005; 38:229-33.

79. Gazzolo D, Abella R, Frigiola A, Giamberti A, Tina G, Nigro F, et al. Neuromarkers and unconventional biological fluids. J Matern Fetal Neonatal Med 2010;3:S66-9.

80. Vaage J, Anderson R. Biochemical markers of neurologic injury in cardiac surgery: the rise and fall of S100beta. J Thorac Cardiovasc Surg 2001;122:853-5.

81. Johnsson P. Markers of cerebral ischemia after cardiac surgery. J Cardiothorac Vasc Anesth 1996;10:120-6.

82. Missler U, Wiesman M, Wittmann G, Magerkurth 0 , Hagenström $\mathrm{H}$. Measurement of glial fibrillary protein in human blood: analytical method and preliminary clinical results. Clin Chem 1999;45:138-41.

83. Johnsson P, Blomquist S, Lührs C, Malmkvist G, Alling C, Solem $\mathrm{J}-0$, et al. Neuron specific enolase increases in plasma during and immediately after extracorporeal circulation. Ann Thorac Surg 2000;69:750-4.

84. Michetti F, Gazzolo D. S100B protein in biological fluids: a tool for perinatal medicine. Clin Chem 2002;48:2097-104.

85. Michetti F, Corvino V, Geloso MC, Lattanzi W, Bernardini C, Serpero L, et al. The S100B protein in biological fluids: more than a lifelong biomarker of brain distress. J Neurochem 2012; 120:644-59.

86. Moore BW. A soluble protein characteristic of the nervous system. Biochem Biophys Res Commun 1965;19:739-44.

87. Zimmer B, Van Eldik LJ. Identification of a molecular target for the calcium-modulated protein S100 fructose-1,6-bisphosphate aldolase. J Biol Chem 1986;261:11424-8.

88. Johnsson H, Johnsson P, Hoglund P, Alling C, Blomquist S. Elimination of $\mathrm{S} 100 \mathrm{~B}$ and renal function after cardiac surgery. J Cardiothorac Vasc Anesth 2000;14:698-701.

89. Rustandi RR, Drohat AC, Baldisseri DM, Wilder PT, Weber DJ. The $\mathrm{Ca}(2+)$-dependent interaction of $\mathrm{S} 100 \mathrm{~B}$ (beta beta) with a peptide derived from p53. Biochemistry 1998;37:1951-60.

90. Wilder PT, Rustandi RR, Drohat AC, Weber DJ. S100B(betabeta) inhibits the protein kinase $C$-dependent phosphorylation of a peptide derived from $\mathrm{p} 53$ in a $\mathrm{Ca}^{2+}$-dependent manner. Protein Sci 1998;7:794-8.

91. Haglid KG, Yang Q, Hamberger A, Bergman S, Widerberg A, Danielsen N. S-100beta stimulates neurite outgrowth in the rat sciatic nerve grafted with acellular muscle transplants. Brain Res 1997;753:196-201.
92. Van Eldik LJ, Wainwright MS. The Janus face of glial-derived S100B: beneficial and detrimental functions in the brain. Restor Neurol Neurosci 2003;21:97-108.

93. Donato R, Sorci G, Riuzzi F, Arcuri C, Bianchi R, Brozzi F, et al. S100B's double life: intracellular regulator and extracellular signal. Biochim Biophys Acta 2009;1793:1008-22.

94. Yang Q, Hamberger A, Hyden H, Wang S, Stigbrand T, Haglid KG. $\mathrm{S}-100$ beta has a neuronal localisation in the rat hindbrain revealed by an antigen retrieval method. Brain Res 1995;696: 49-61.

95. Santamaria-Kisiel L, Rintala-Dempsey AC, Shaw GS. Calciumdependent and -independent interactions of the S100 protein family. Biochem J 2006;396:201-14.

96. Haimoto H, Hosoda S, Kato K. Differential distribution of immunoreactive S100-alpha and S100-beta proteins in normal non nervous human tissues. Lab Invest 1987;57:489-98.

97. Michetti F, Dell'Anna E, Tiberio G, Cocchia D. Immunochemical and immunocytochemical study of S-100 protein in rat adipocytes. Brain Res 1983;262:352-6.

98. Marinoni E, Di lorio R, Gazzolo D, Lucchini C, Michetti F, Corvino $\mathrm{V}$, et al. Ontogenetic localization and distribution of S-100beta protein in human placental tissues. Obstet Gynecol 2002;99: 1093-9.

99. Wijnberger LD, Nikkels PG, van Dongen AJ, Noorlander CW, Mulder EJ, Schrama LH, et al. Expression in the placenta of neuronal markers for perinatal brain damage. Pediatr Res 2002; 51:492-6.

100. Gazzolo D, Marinoni E, di lorio R, Lituania M, Bruschettini PL, Michetti F. Circulating S100beta protein is increased in intrauterine growth-retarded fetuses. Pediatr Res 2002;51: 215-9.

101. Kanner AA, Marchi N, Fazio V, Mayberg MR, Koltz MT, Siomin V, et al. Serum S100beta: a noninvasive marker of blood-brain barrier function and brain lesions. Cancer 2003;97:2806-13.

102. Müller K, Elverland A, Romner B, Waterloo K, Langbakk B, Undén J, et al. Analysis of protein S-100B in serum: a methodological study. Clin Chem Lab Med 2006;44:1111-4.

103. Bouvier D, Duret T, Rouzaire P, Jabaudon M, Rouzaire M, Nourrisson C, et al. Preanalytical, analytical, gestational and pediatric aspects of the S100B immuno-assays. Clin Chem Lab Med 2016;54:833-42.

104. Oris C, Chabanne R, Durif J, Kahouadji S, Brailova M, Sapin V, et al. Measurement of S100B protein: evaluation of a new prototype on a bioMérieux Vidas ${ }^{\circledR} 3$ analyzer. Clin Chem Lab Med 2019;57:1177-84.

105. Gazzolo D, Pluchinotta F, Lapergola G, Franchini S. The $\mathrm{Ca}^{2+}$ binding S100B protein: an important diagnostic and prognostic neurobiomarker in pediatric laboratory medicine. Methods Mol Biol 2019;1929:701-28.

106. Hernández-García C, Rodríguez-Rodríguez A, Egea-Guerrero JJ. Brain injury biomarkers in the setting of cardiac surgery: still a world to explore. Brain Inj 2016;30:10-7.

107. Jönsson H, Johnsson P, Birch-lensen M, Alling C, Westaby S, Blomquist S. S100B as a predictor of size and outcome of stroke after cardiac surgery. Ann Thorac Surg 2001;71:1433-7.

108. Herrmann M, Ebert AD, Galazky I, Wunderlinch MT, Kunz WS, Huth C. Neurobehavioral outcome prediction after cardiac surgery: role of neurobiochemical markers of damage to neuronal and glial brain tissue. Stroke 2000;31:645-50. 
109. Iskesen I, Kurdal AT, Yilmaz H, Cerrahoglu M, Sirin BH. Sleep disturbances after cardiac surgery with or without elevated S100B levels. Acta Cardiol 2009;64:741-6.

110. Kilminster S, Treasure T, McMillan T, Holt DW. Neuropsychological change and S-100 protein release in 130 unselected patients undergoing cardiac surgery. Stroke 1999; 30:1869-74.

111. Westaby S, Saatvedt K, White S, Katsumata T, van Oeveren W, Bhatnagar NK, et al. Is there a relationship between serum $\mathrm{S}$-100beta protein and neuropsychologic dysfunction after cardiopulmonary bypass? J Thorac Cardiovasc Surg 2000;119: 132-7.

112. Krnjak L, Trunk P, Gersak B, Osredkar J. Correlation of serum S100B concentration with hospital stay in patients undergoing CABG. Acta Clin Croat 2008;47:221-6.

113. Nygaard $\emptyset$, Langbakk B, Romner B. Age- and sex-related changes of S-100 protein concentrations in cerebrospinal fluid and serum in patients with no previous history of neurological disorder. Clin Chem 1997;43:541-3.

114. Ali MS, Harmer M, Vaughan R. Serum S100 protein as a marker of cerebral damage during cardiac surgery. $\mathrm{Br}$ J Anaesth 2000;85: 287-98.

115. Anderson RE, Hansson LO, Vaage J. Release of S100B during coronary artery bypass grafting is reduced by off-pump surgery. Ann Thorac Surg 1999;67:1721-5.

116. Jönsson H, Johnsson P, Alling C, Bäckström M, Bergh C, Blomquist S. S100 $\beta$ after coronary surgery: release pattern, source of contamination, and relation to neuropsychological outcome. Ann Thorac Surg 1999;68:2202-8.

117. Anderson R, Hansson L-O, Liska J, Settergren G, Vaage J. The effect of the cardiotomy suction on the brain injury marker S100 $\beta$ after cardiopulmonary bypass. Ann Thorac Surg 2000;69: 847-50.

118. Anderson R, Hansson L-O, Nilsson O, Liska J, Settergren G, Vaage J. Increase in serum S100A1-B and S100BB during cardiac surgery arises from extracerebral sources. Ann Thorac Surg 2001;71:1512-7.

119. Zheng L, Fan QM, Wei ZY. Serum S-100ß and NSE levels after offpump vs. on-pump coronary artery bypass graft surgery. BMC Cardiovasc Disord 2015;15:70-83.

120. Babin-Ebell J, Roth P, Reese J, Bechtel M, Mortasawi A. Serum S100B levels in patients after cardiac surgery: possible sources of contamination. Thorac Cardiovasc Surg 2007;55:168-72.

121. Missler U, Orlowski N, Nötzold A, Dibbelt L, Steinmeier E, Wiesmann M. Early elevation of S-100B protein in blood after cardiac surgery is not a predictor of ischemic cerebral injury. Clin Chim Acta 2002;321:29-33.

122. Wang S, Wang L, Zhang X, Wang C, Zheng G, Wu W, et al. Effects of subcutaneous low molecular weight heparin and intravenous unfractionated heparin on serum S100 concentrations in patients with cerebrovascular diseases. Clin Chem Lab Med 2012;50:525-8.

123. Chen F, Duan G, Wu Z, Zuo Z, Li H. Comparison of the cerebroprotective effect of inhalation anaesthesia and total intravenous anaesthesia in patients undergoing cardiac surgery with cardiopulmonary bypass: a systematic review and metaanalysis. BMJ Open 2017;7:e014629.

124. Zhou T, Li S, Xiang D, Gao L. Effects of isolated impaired fasting glucose on brain injury during cardiac surgery under cardiopulmonary bypass. J Invest Surg 2020;33:350-8.
125. Bar-Yosef O, Greidinger D, Iskilova M, Hemi R, Tirosh T, Vardi A. Neurological deficit is predicted by $\mathrm{S} 100 \mathrm{~B}$ in children after cardiac surgery. Clin Chim Acta 2018;481:56-60.

126. Westaby S, Johnson P, Parry AJ, Blomqvist S, Solem JO, Alling C, et al. Serum S100 protein. A potential marker for cerebral events during cardiopulmonary by-pass. Ann Thorac Surg 1996;61: 88-92.

127. Gazzolo D, Vinesi P, Geloso MC, Marcelletti C, lorio FS, Cipriani A, et al. S100 blood concentrations in children subjected to cardiopulmonary by-pass. Clin Chem 1998;44:1058-60.

128. Gazzolo D, Masetti P, Vinesi P, Meli M, Abella R, Marcelletti C, et al. S100B blood levels correlate with rewarming time and cerebral Doppler in pediatric open heart surgery. J Card Surg 2002;17:279-84.

129. Abu-Sultaneh S, Hehir DA, Murkowski K, Ghanayem NS, Liedel J, Hoffmann RG, et al. Changes in cerebral oxygen saturation correlate with S100B in infants undergoing cardiac surgery with cardiopulmonary bypass. Pediatr Crit Care Med 2014;15: 219-28.

130. Bokesch PM, Appachi E, Cavaglia M, Mossad E, Mee RB. A glialderived protein, $\mathrm{S} 100 \mathrm{~B}$, in neonates and infants with congenital heart disease: evidence for preexisting neurologic injury. Anesth Analg 2002;95:889-92.

131. Varrica A, Satriano A, Gavilanes ADW, Zimmermann LJ, Vles HJS, Pluchinotta F, et al. S100B increases in cyanotic vs. noncyanotic infants undergoing heart surgery and cardiopulmonary bypass (CPB). J Matern Fetal Neonatal Med 2019;32:1117-23.

132. Matheis G, Abdel-Rahman U, Braun S, Wimmer-Greinecker G, Esmaili A, Seitz U, et al. Uncontrolled reoxygenation by initiating cardiopulmonary bypass is associated with higher protein S100 in cyanotic vs. acyanotic patients. Thorac Cardiovasc Surg 2000; 48:263-8.

133. Peng YW, Major T, Mohammed A, Deatrick KB, Charpie JR. Normoxic re-oxygenation ameliorates end-organ injury after cardiopulmonary bypass. J Cardiothorac Surg 2020;15:134-43.

134. Caputo M, Mokhtari A, Miceli A, Ghorbel MT, Angelini GD, Parry AJ, et al. Controlled reoxygenation during cardiopulmonary bypass decreases markers of organ damage, inflammation, and oxidative stress in single-ventricle patients undergoing pediatric heart surgery. J Thorac Cardiovasc Surg 2014;148: 792-801.

135. Innken K, Morita K, Buckberg GD, Ignarro LJ, Beyersdorf F. Reduction of reoxygenation injury and nitric oxide production in the cyanotic immature heart by controlling p02. Eur J Cardio Thorac Surg 1995;9:410-8.

136. Ihnken K, Morita K, Buckberg GD. Delayed cardioplegic reoxygenation reduces reoxygenation injury in cyanotic immature hearts. Ann Thorac Surg 1998;66:177-82.

137. Caputo M, Mokhtari A, Rogers CA, Panayiotou N, Chen Q, Ghorbel MT, et al. The effects of normoxic vs. hyperoxic cardiopulmonary bypass on oxidative stress and inflammatory response in cyanotic pediatric patients undergoing open cardiac surgery: a randomized controlled trial. J Thorac Cardiovasc Surg 2009;138:206-14.

138. Bulutcu FS, Bayindir O, Polat B, Yalcin Y, öZbek U, Cakali E. Does normoxemic cardiopulmonary bypass prevent myocardial reoxygenation injury in cyanotic children? J Cardiothorac Vasc Anesth 2002;16:330-3.

139. Nagdyman N, Ewert P, Schmitt K, Hübler M, Stiller B, Müller C, et al. Protein S-100 is present in extracerebral fluids before and 
after cardiac surgery in children. Ann Clin Biochem 2008;45: 409-12.

140. Snyder-Ramos SA, Gruhlke T, Bauer H, Bauer M, Luntz AP, Motsch J, et al. Cerebral and extracerebral release of protein S100B in cardiac surgical patients. Anaesthesia 2004;59: 344-9.

141. Jönsson H, Johnsson P, Bäckström M, Alling C, Dautovic-Bergh C, Blomquist S. Controversial significance of early S100B levels after cardiac surgery. BMC Neurol 2004;4:24-31.

142. Jönsson H. S100B and cardiac surgery: possibilities and limitations. Restor Neurol Neurosci 2003;21:151-7.

143. Svenmarker S, Engström KG. The inflammatory response to recycled pericardial suction blood and the influence of cellsaving. Scand Cardiovasc J 2003;37:158-64.
144. Varrica A, Satriano A, Frigiola A, Giamberti A, Tettamanti G, Anastasia L, et al. Circulating S100B and adiponectin in children who underwent open heart surgery and cardiopulmonary bypass. Biomed Res Int 2015;2015:402642.

145. Gazzolo D, Masetti P, Kornacka M, Abella R, Bruschettini P, Michetti F. Phentolamine administration increases blood S100B protein levels in pediatric open-heart surgery patients. Acta Paediatr 2003;92:1427-32.

146. Bashir M, Frigiola A, Iskander I, Said HM, Aboulgar H, Frulio R, et al. Urinary S100A1B and S100BB to predict hypoxic ischemic encephalopathy at term. Front Biosci (Elite Ed) 2009; 1:560-7.

147. Yuan SM. Biomarkers of cerebral injury in cardiac surgery. Anadolu Kardiyol Derg 2014;14:638-45. 